\title{
PARTNERSHIP AND COLLABORATION IN WORK-ORIENTED LEARNING IN HIGHER EDUCATION
}

\author{
Dr. Muir Houston \\ Senior Lecturer (Social Justice Place and Lifelong Education) \\ College of Social Sciences, School of Education, \\ University of Glasgow, R223 Level 2, St. Andrews Building, United Kingdom \\ Muir.Houston@glasgow.ac.uk

\section{Dr. Karsten Krueger} \\ Fundación Conocimiento y Desarrollo \\ Pl. Francesc Macià, 4, 08021 Barcelona, Spain \\ Karsten.Krueger@fundacioncyd.org

\section{Prof. Mike Osborne} \\ Chair of Adult \& Lifelong Education (Social Justice Place and Lifelong Education) \\ College of Social Sciences, School of Education, University of Glasgow \\ R223 Level 2, St. Andrews Building, United Kingdom \\ Michael.Osborne@glasgow.ac.uk
}

\section{ABSTRACT}

The paper reports preliminary findings from an EU funded project on collaboration and partnership between external stakeholders and universities to deliver workrelated learning to adults with existing labour market experience in order to increase skills and competences for the knowledge economy as envisaged in Agenda 2020. The paper engages with debates on the professionalization of vocational education and consequently the vocationalisation of university education. It reports relevant data for the six partner countries of the LETAE project and EU averages to provide some context to debates about relative levels of attainment and labour market position. It briefly introduces some data drawn from case studies of work-related learning in higher education delivered in partnership or collaboration with external stakeholders including local authorities, trade unions, and individual enterprises.

Key words: work-related learning; higher education, VET; permeability; external stakeholders; EU; attainment; labour markets; partnership.

\section{WORK ORIENTED LEARNING IN HIGHER EDUCATION}

\section{VOCATIONALISATION OF HIGHER EDUCATION}

Higher education (HE) has in the last few decades experienced a considerable transformation, which can be identified by two trends: a) Academic drift in the sense of traditional vocational education at secondary and post-secondary level becoming 'professional' at tertiary 'academic' education levels (Kyvik, 2004; Harwood, 2010); and, b) Vocational drift whereby VET principles are integrated into higher education in the form of new teaching and learning methods, internships and different types of dual studies and sandwich programmes 
(Hippach-Schneider, 2014). Both trends can be subsumed under the term of the vocationalisation of higher education. ${ }^{1}$

Alongside other drivers such as technological developments and structural changes in the economy that impacted on the labour market; the main driving force of change in HE was the increasing massification of higher education accompanied by the universalisation of the higher education offer. ${ }^{2}$ The objective of the new EU strategy is to achieve a goal of $40 \%$ of $25-35$ year olds in higher education consolidating the trend towards universalisation. ${ }^{3}$

One significant effect of the increasing proportion of the population accessing and participating in higher education is that of 'crowding out'. Simply put, changes in the supply of graduates have not been matched by changes in demand in the labour market; thus it is suggested that those graduates, who are unable to find employment in the traditional areas requiring academic qualifications, enter into the 'non-academic' labour market. ${ }^{4}$ This trend is said to have contributed to a redefinition of occupational profiles including a stronger academic orientation and in consequence, an increase in the demand for academic qualifications in occupations previously intended for those with primarily vocational qualifications. Smeby (2015) analysed this process for teaching, nursery and social work, where the process of upgrading from vocational programmes to higher education has been taking place for the last 40 years. ${ }^{5}$ Elsewhere in the labour market this has led to changes in the demand for skills as a result of changes to the manufacturing and service processes though technological change and innovation. It is suggested that this has increased demand for more generic analytical skills and reduced demand for narrowly defined job-specific skills (see Mayer \& Solga, 2008, p. 1-4; Solga, 2009; Streeck, 2011). Moreover, the rise in the level of average skill requirements in the service economy and knowledge society (e.g., Kuhn et al., 2009; Buhr et al., 2008) brings into question the traditional divide between VET and HE, producing a vocationalisation of $\mathrm{HE}$.

At the same time, as Skorstad and Ramsdal (2009) explain, the removal of traditional job demarcations inherent to job specific skills has had the effect of introducing functional flexibility which allows for the employment of semi-skilled or unskilled labour. Those with academic qualifications, particularly young workers desperate for employment, fall into this category of under-employment (Bell \& Blanchflower, 2013; Allen, 2015). At the same time, the EU goal of $40 \%$ entering HE, taken up enthusiastically by governments across the EU, together with the continuing aftermath of the 2008 Great Financial Crisis, has resulted in employers having a much bigger pool of labour from which to choose (Standing, 2011) so the

\footnotetext{
$\overline{1}$ This is not a completely new trend. For instance, Leroux (2014) explains that the vocationalisation of French higher education began in 1960. Since then, non-university higher education institutions have been established in a number of other European countries (e.g. Germany and the Netherlands).

2 This is also not a new trend. Windolf (1992) showed that from the 1920s until the 1980s there was a consistent increase in the number of students in countries as diverse as Germany, Italy, France, Japan and the United States; while Meyer and colleagues (Meyer et al., 1977; Schofer and Meyer, 2005) have analysed the dramatic world-wide expansion of higher education provision after World-War II.

3 Trow (1974 and 2005) has forecasted structural changes, which accompany the universalisation of higher education.

4 However, there were and are always some higher education trajectories with a stronger orientation to professionalization in the fields of law, education, medicine, veterinary science, dentistry, engineering etc. compared to more academically fields as physics, chemistry, sociology, biology, history etc. In addition, many countries still have elite institutions that are largely unaffected by such trends.

5 "The curriculum has shifted from a craft model, with emphasis on learning through experience, to a more academic one." (Smeby 2015: 7).
} 
call for greater permeability between the fields of VET and HE has become more strident.

One major expression of the structural changes is the curricular reforms to implement the three-cycle structure promoted by the Bologna Process. ${ }^{6}$ It stated that Bachelor degrees should have a strong orientation to the labour market i.e. to employability, and concomitant a stronger vocational orientation.

A second is the existence of additional certificates below the Bachelor degree with a stronger vocational orientation (for instance the French Brevet de Technician Supérieur (BTS) or the Foundation Degree in England, Wales and Northern Ireland) ${ }^{7}$

A third is the introduction of specialist degrees (generally at Bachelor level) with long periods of workplace learning, such as Dual Studies (e.g. Germany and Austria), Alternance Programs (France) and Sandwich Programmes (UK). In some countries, for instance Spain, there is a trend to distinguish between professional and academic masters (see CEDFOP, 2011).

A fourth is increasing innovation in teaching and learning; mainly concerned with introducing workplace learning into the curriculum, or to simulate real work situations through strategies such as Cooperative Learning, Problem Based Learning, Project Oriented Learning and, most recently, Service Learning and Research Based Learning (Yorke and Knight, 2006). Specifically in relation to employability an increasing number of degree programmes are offering some form of internship or placement to students during their undergraduate study. However, these changes are not only designed to respond to vocationalisation, but also to policy initiatives, designed to ensure closer cooperation and greater engagement between employers and enterprises and universities in order to respond more effectively to the challenges of the knowledge economy; and changes in research procedures, which are increasingly focused on public-private cooperation and interdisciplinary work.

A fifth is the degree of permeability between VET and $\mathrm{HE}^{8}$ expressed through Recognition of Prior Learning (RPL) and the Accreditation of Prior Leaning (APL). R/APL is a priority for educational policies Europe-wide and on the agenda of many European countries; and, while in theory it is available in some member states, as suggested in the European Credit Transfer System (EC, 2015b), its acceptance and the level and amount of credit awarded varies considerably both within and across member states (Lafont and Pariat, 2012). ${ }^{9}$ The introduction of R/APL is a way to establish new and more flexible education trajectories for the transition between VET and HE; and, again, moves in this direction have

\footnotetext{
$6 \quad$ One of the main objectives was to ensure a closer relation of, at least, the bachelor degree to the labour market: "The degree awarded after the first cycle shall also be relevant to the European labour market as an appropriate level of qualification. The second cycle should lead to the master and/or doctorate degree as in many European countries." (Bologna Declaration). The issue of employability was one of the guidelines of the Bologna Process at its inception and this was re-affirmed in 2015 by a Ministerial Document (EGEA Ministerial Conference (2015).

7 This question make reference to the qualification at the EQF level 5, which are located in the higher education sector of the education system. In Scotland, site of two of the UK case studies, a system of sub-degree Higher National Certificates and Diplomas operates

8 Permeability between education trajectories is one of the main issues coming out of recent EU strategies (see Bruges communiqu from 2010) linked on the one hand to the objective of widening participation in higher education and on the other to the social equity role of education.

9 As an equivalent to the ECTS, the EC has developed an equivalent for VET - the European Credit system for Vocational Education and Training (ECVET). But as the introduction of the ECVET hasn't been accompanied by a standardisation process similar to the Bologna process, its implementation is uneven.
} 
been made at both the EU level with the introduction of the EQF (European Qualification Framework) and similar moves in member states in the development of NQFs (National Qualifications Frameworks). However, as with the ECTS, progress is varied (CEDEFOP, 2012).

Last but not least, the vocationalisation of HE introduced closer universitybusiness cooperation in the field of education. It is seen as crucial to the employability agenda for greater integration of internships and placements into the formal university curriculum. This cooperation in the field of education is accepted Europe-wide as of major importance, but effective cooperation differs from country to country. ${ }^{10}$ For instance, a number of EU documents have argued for a deeper engagement with stakeholders ${ }^{11}$ (EC, 2012a), especially from business in the definition and in some cases co-construction of the higher education curriculum ${ }^{12}$.

It is recognised that curriculum development is often slow to respond to changes in the labour market and work requirements (see Krüger and Jiménez) however, Teichler drew attention to the opinion of stakeholders on developments in the labour market often being mistaken as objective information. He found that, in contrast, they frequently displayed a short-term vision centred on their own business area. “Employers' statements, as a rule, say little about the proactive role higher education could play with regard to the world of work" (Teichler 1999, p. 293).

The debate on the involvement of stakeholders in curriculum design is linked to the type of knowledge, skills and competence higher education is expected to deliver. Higher education knowledge, skills and competence differ substantially from those associated with other levels of education and training institutions. "Graduates are expected to perform well in the framework of established job requirements and professional practices, but they are also trained to constantly reflect and challenge the established links between knowledge and work tasks." (Teichler 2007, p. 17)

In these circumstances, the crucial question is how higher education can maintain their specific characteristics while at the same time responding to the challenges of diverse labour market sectors.

One way promoted by the European Union is (tertiary) lifelong learning. In its 2011 resolution on modernising universities for Europe's competitiveness in a global economy, the Council claims: "to improve the identification of training needs, increase the labour market relevance of education and training, facilitate individuals' access to lifelong learning opportunities and guidance, and ensure smooth transitions between the worlds of education, training and employment." (Council of the European Union, 2011, p. 2).

Higher education systems need to increase lifelong learning opportunities, widen access to higher education, booster employability and upgrade the skills

10 "Although the involvement of the labour market in VET provision at higher qualification levels is widely recognised in all countries, the level and forms of involvement of labour market actors is varied. In some countries the effectiveness of this link is limited (e.g. the Czech Republic, Poland, Portugal and Romania). In other countries, it is significant and implemented through a variety of forms, e.g. through work placements in Denmark, Germany and Finland. Further, sectoral bodies and social partners have a major influence on VET provision in some countries, e.g. Germany (where the cooperation with labour market actors often occurs at a regional level), and France and Norway for education institutions" (CEDEFOP 2011: 9).

11 See for instance EC (2006) Delivering on the Modernisation Agenda for Universities: Education, research and Innovation; EC (2011) Supporting growth and jobs - An Agenda for the modernisation of Europe's higher education systems, com (2011) 567 final Luxembourg; and Council of the European Union (2011) Council conclusion on the modernisation of higher education. Brussels

12 Involving business and labour market stakeholders in the design of curricula "can help to attune curricula to current and emerging labour market needs and foster employability and entrepreneurship" (EC 2011: 6) 
of the population. This includes the broader integration of non-traditional learners in programmes of the Bologna scheme, but also the provision of specific programme for adult learners, which will have primarily a labour market orientation. In the strategy paper Supporting growth and jobs - an agenda for the modernisation of Europe's higher education systems (EC, 2011) one of the key policy recommendations is to encourage a greater variety of study modes (e.g. part-time, distance and modular learning, continuing education) for adult returners and others already in the labour market.

\section{UNIVERSITY ADULT EDUCATION IN SIX EUROPEAN COUNTRIES}

In the following section, we present some preliminary results from the study on university-enterprise cooperation in the field of tertiary lifelong learning (TLL) and university adult education; or, what under the Liberal Arts Education tradition in the UK would be seen as Continuing Education. We try to provide answers to the following research questions:

- $\quad$ To what extent are universities cooperating with enterprises and external stakeholders in the field of university adult education?

- Will this cooperation lead to increases in the effectiveness of university adult education?

The Labour Efficiency of Tertiary Adult Education (LETAE) project (funded by the EU under its Lifelong Learning Programme) ${ }^{13}$ was concerned to identify good practice in partnerships and collaborations between enterprises, work organisations and employer groups and higher education institutions. It built on the Tertiary Higher Education for Mid-life People (THEMP) ${ }^{14}$ project which concentrated on pedagogical issues related to adult learners in higher education; while in LETAE we explored work-based/-related elements of such programmes with a focus on partnerships and collaborations with external stakeholders. LETAE aimed to identify areas of good practice in the development of programmes in collaboration with industry, employers, sectoral organisations, trade unions and professional or regulatory bodies. We were also concerned with what the drivers of such programmes are in terms of internal or external factors; and, how and in what ways national policy contexts, regulatory frameworks and labour market structures may influence this process.

The projects adopted a Multiple-Case Study research strategy with embedded units of analysis (Yin, 2014), which compared different tertiary level work-based or work-related programmes for adult learners $(>25)$ both within and across a cluster of EU Member States (CZ, DE, ES, FL, UK) and Turkey. Theoretically, LETAE had three components: an individual focus on personal development, perceptions and behaviour; an organisational focus on processes, structures, functions and collaborations; and a social element in relation to issues of inclusion, transitions and outcomes. Each partner selected three case studies. ${ }^{15}$

The project was specifically concerned with the relevance of university provision and its impact on adult learners in the labour market and its influence

\footnotetext{
13 Project Number: 539382-LLP-1-2013-1-ES-ERASMUS-EQR

14 http://www.themp.eu/

15 At the core of each case study stands an analysis of available data, documentary analysis of institutional/organisational websites and documents in the public domain. In order to allow some level of comparability semi-structured interview schedules for each of the three groups of interest (learners, academics, and external partners) were designed to be applied across all cases.
} 
on their work performance. For this reason, examples of business-university cooperation in the field of initial education programmes, in which the majority of participants enter direct from compulsory education were excluded. This included for example programmes like Nursing and Teaching, Medicine and Dentistry where it could well be argued that these also offer what might be seen as work-based and work-related learning (Ramage, 2014). Whilst this is undoubtedly true, the focus here is on broader conceptions of work-based and -related learning and as noted at the level of collaboration and partnership between external stakeholders and institutions of higher education in the provision of WBL programmes.

In the following section, we explore contextual information putting emphasis on the six countries under scrutiny in LETAE. In the third section, we provide a short analysis of the respective national landscapes of university adult education using two dimensions: a) the degree of institutional diversity of higher education and b) the identified focus of university adult education. We focus on two aspects of the EU lifelong learning strategy: a) opening the higher education for non-traditional learners (permeability) and b) the constant updating of knowledge, skills and competences of the working population (continuous training). This allows us to identify the United Kingdom and Spain as two countries, with very different university adult education strategies. While in the UK-higher education system, the strategic focus lies on permeability, the Spanish system focuses its attention on continuous training mainly in the form of post-graduate programmes. In the fourth section, we then present the cases studied in both countries in the course of the LETAE project to analyse the relevance of university-enterprise cooperation for both strategies. In the final section, we present some general conclusions.

\section{NATIONAL CONTEXT DATA}

Having outlined a number of theoretical and policy debates at the national and EU levels it is instructive to note how and in what ways the socio-economic structural changes noted above and the policy proscriptions implemented in order to try and respond and address the social impact of the changes have manifested themselves in each of the LETAE member states. In order to provide some context within which to situate the case studies, it is instructive to have a brief look at some comparative data related to education, training and employment. In addition, we also provide details on education expenditure as a percentage of GDP and also in relation to student tuition charges and support. ${ }^{16}$ To allow comparison we adopt the ISCED 2011 classification (UNESCO, 2011) unless specified. ${ }^{17}$

It is suggested that one measure of national interest in relation to postcompulsory education is the support provided in relation to not only the share of GDP it allocates to compulsory and post-compulsory education; but also how students finance their tuition and subsistence. Education at a Glance (OECD, 2014) provides details on the percentage of GDP (Gross Domestic Product) each of the partner countries spends on tertiary and non-tertiary education.

$16 \quad$ Figures and tables are adapted from OECD and Eurostat source data.

17 ISCED 0-2: people with low education level which comprises those with early childhood education (0), primary education (1) or lower secondary education (2); ISCED 3-4: people with medium education level: those with upper secondary (3) and post-secondary non-tertiary education (4); and, ISCED 5-8: people with high education level: comprising those with short-cycle tertiary education (5), Bachelor's or equivalent (6), Master's or equivalent level (7) and Doctoral or equivalent level (8). 


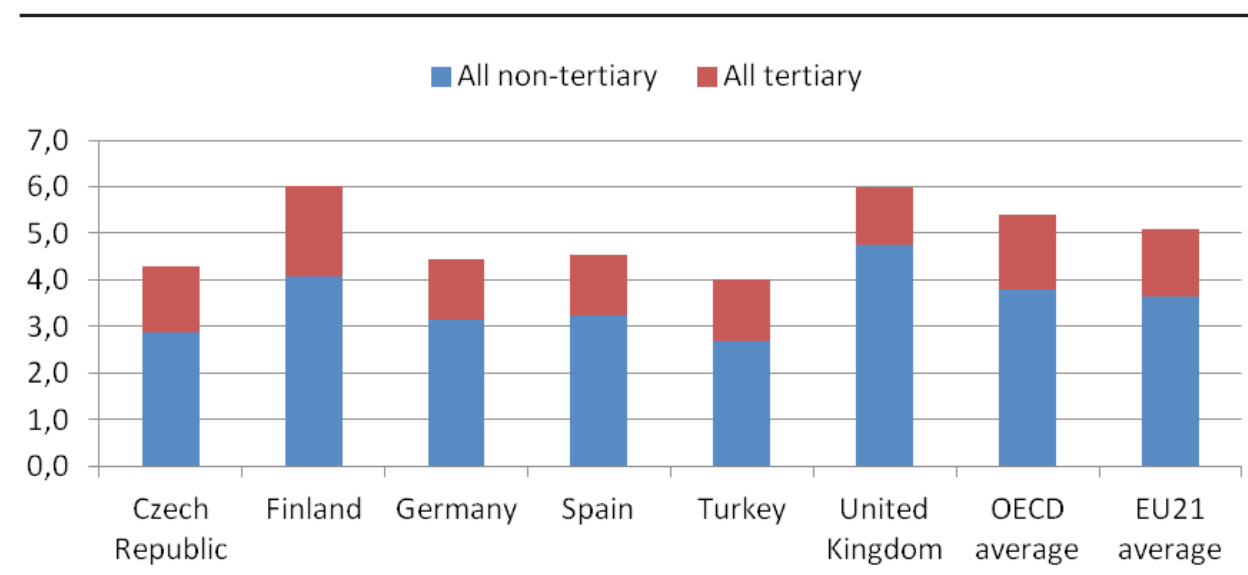

Figure 1: Expenditure on educational institutions as a percentage of GDP, by level of education - 2011

(Source: adapted from OECD, 2014: Table B2.1, p. 230)

Overall, on both tertiary and non-tertiary, only the UK and Finland spend a greater percentage of GDP in comparison with not only the other partner countries; ${ }^{18}$ but also the OECD and EU21 averages. However, it is suggested that the effects of increased marketization of tertiary education in the UK can also be seen; in that it not only spends less than project partners but also less than the OECD and EU 21 averages on tertiary level education. The four other partner countries devote a similar level of resource to both tertiary and non-tertiary education although the levels of spending on non-tertiary are lower than EU and OECD averages.

There is greater disparity when the costs of higher education are compared across the partner countries. Table 1 is adapted from National Student Fees and Support Systems (Eurydice, 2014) and provides a very brief overview of the most salient elements of the costs of higher education and how and in what ways this is supported by the state or increasingly the contribution that is expected from the individual students either upfront or in the form of income contingent repayable loans. Two things are apparent from the table, illustrated by the two extreme responses to student funding; England in the UK represents the highest fees, and it is argued the most commodified HE system in Europe, while with no fees at all at undergraduate level Finland perhaps represents best the notion of $\mathrm{HE}$ as a truly public good.

Table 1

Fees and financial support for higher education

\begin{tabular}{|c|l|l|}
\hline & \multicolumn{1}{|c|}{ Fees } & \multicolumn{1}{|c|}{ Support } \\
\hline 1 & \multicolumn{1}{|c|}{2} & \multicolumn{1}{|c|}{3} \\
\hline CZ & $\begin{array}{l}\text { Minimal administration charge and } \\
\text { no fees; international students pay } \\
\text { no fees unless in foreign language } \\
\text { instruction }\end{array}$ & $\begin{array}{l}\text { Some support dependent upon } \\
\text { need, excellence, location - family } \\
\text { allowances and tax benefits for } \\
\text { parents }\end{array}$ \\
\hline DE & $\begin{array}{l}\text { Small administrative charge but no } \\
\text { fees - no fees EU, outside EU and } \\
\text { EAA members }\end{array}$ & $\begin{array}{l}\text { General public and merit based } \\
\text { grants plus loans (age limited }<30)- \\
\text { family allowances and tax relief }\end{array}$ \\
\hline
\end{tabular}

18 It should be noted that this includes public and private sources of funding. 


\begin{tabular}{|c|c|c|}
\hline \multicolumn{3}{|r|}{ Continuation of Table 1} \\
\hline 1 & 2 & 3 \\
\hline ES & $\begin{array}{l}\text { Multiple fees systems based on } \\
\text { ECTS; exemptions by need; } \\
\text { individual responsibility ( } 15-25 \% \text { of } \\
\text { fees) - non EU higher fees }\end{array}$ & $\begin{array}{l}\text { Tuition fee waiver plus national } \\
\text { grant - no tax benefits or family } \\
\text { allowances }\end{array}$ \\
\hline FI & No fees & $\begin{array}{l}\text { Study grant and housing supple- } \\
\text { ment - income dependent - study } \\
\text { loans available - no tax benefits or } \\
\text { family allowances }\end{array}$ \\
\hline TK & $\begin{array}{l}\text { Public universities differential fees } \\
\text { morning or evening; not for profit } \\
\text { fee discounts available; } 1^{\text {st }} \text { and } 2^{\text {nd }} \\
\text { Cycle differential }\end{array}$ & $\begin{array}{l}\text { Various forms of grants in form of } \\
\text { scholarships and learning credits; } \\
\text { loans - no tax benefits or allowances }\end{array}$ \\
\hline \multirow[t]{2}{*}{ UK } & $\begin{array}{l}\text { England: expensive tuition fees } \\
\text { (max } € 11,000 \text { p.a.) repayable as } \\
\text { income contingent for home and } \\
\text { EU students; international fees not } \\
\text { regulated }\end{array}$ & $\begin{array}{l}\text { Low income grants now abolished - } \\
\text { loans repayable as with fees - no tax } \\
\text { benefits or allowances }\end{array}$ \\
\hline & $\begin{array}{l}\text { Scotland: no tuition fees for home } \\
\text { and EU - but fees payable by Rest } \\
\text { of UK students; International fees } \\
\text { unregulated }\end{array}$ & $\begin{array}{l}\text { Grants for low income and loans - } \\
\text { income contingent repayable - no } \\
\text { tax benefits or allowances }\end{array}$ \\
\hline
\end{tabular}

(Source: adapted from Eurydice 2014)

We now turn to look at the distribution of qualifications across the population of the LETAE partners and the EU28 and provide data for pre- and post-crisis. Table 2 provides details of those aged 25-64 by education measured by ISCED 2011 for both 2007 and 2014 and by gender.

Table 2

Population share (\%) by level of education (ISCED 2011) and gender (age 25-64): 2007 and 2014

\begin{tabular}{|c|c|c|c|c|c|c|c|c|c|c|c|c|}
\hline & \multicolumn{9}{|c|}{ 2007 } & \multicolumn{4}{c|}{ Male } & \multicolumn{3}{c|}{ Female } \\
\hline & \multicolumn{3}{|c|}{ Male } & \multicolumn{3}{c|}{ Female } & \multicolumn{3}{c|}{ Mal4 } \\
\hline ISCED & $0-2$ & $3-4$ & $5-8$ & $0-2$ & $3-4$ & $5-8$ & $0-2$ & $3-4$ & $5-8$ & $0-2$ & $3-4$ & $5-8$ \\
\hline EU28 & 27.8 & 49.0 & 23.2 & 30.8 & 45.5 & 23.8 & 23.7 & 48.4 & 27.9 & 24.3 & 45.0 & 30.7 \\
\hline CZ & 6.1 & $\underline{\mathbf{7 9 . 0}}$ & 14.8 & 12.8 & $\underline{74.6}$ & 12.6 & 4.8 & $\underline{74.5}$ & 20.7 & 8.8 & $\underline{68.8}$ & 22.4 \\
\hline DE & 12.6 & $\underline{59.6}$ & 27.8 & 18.6 & $\underline{60.6}$ & 20.8 & 11.3 & $\underline{58.3}$ & 30.5 & 14.9 & $\underline{61.4}$ & 23.7 \\
\hline ES & 49.7 & 21.7 & 28.6 & 49.0 & 21.1 & 30.0 & 45.2 & 22.0 & 32.8 & 41.6 & 21.9 & 36.5 \\
\hline FI & 21.7 & 47.2 & 31.1 & 17.3 & 41.1 & $\mathbf{4 1 . 7}$ & 16.1 & 48.7 & 35.2 & 10.8 & 40.7 & $\mathbf{4 8 . 5}$ \\
\hline HU & 23.8 & $\underline{66.2}$ & 16.5 & 28.7 & $\underline{56.1}$ & 19.6 & 20.8 & $\underline{64.9}$ & 20.2 & 23.2 & $\underline{54.8}$ & 26.3 \\
\hline IT & 49.7 & 39.1 & 12.4 & 47.7 & 38.2 & 14.7 & 44.2 & 42.7 & 14.9 & 40.5 & 42.1 & 18.9 \\
\hline NL & 30.0 & 42.9 & 32.9 & 32.9 & 41.9 & 28.7 & 28.4 & 42.4 & 34.8 & 29.1 & 40.7 & 34.1 \\
\hline UK & 23.5 & 44.9 & 31.6 & 29.8 & 37.7 & 32.5 & 19.6 & 41.2 & $\mathbf{3 9 . 2}$ & 22.0 & 36.1 & $\mathbf{4 1 . 9}$ \\
\hline TR & 66.9 & 20.5 & 12.6 & 79.8 & 12.4 & 7.7 & 61.3 & 21.0 & 17.8 & 73.6 & 13.6 & 12.8 \\
\hline
\end{tabular}

(Source: adapted from Eurostat) 
Overall, a comparison of the data identifies some general trends:

a) A reduction in the rate of people with low levels of educational attainment, although the magnitude is relatively small suggesting much has to be done if skill levels suggested in Europe 2020 and related predictions are to be reached. Of particular interest, the country with the lowest levels of ISCED 0-2 for both males and females is the Czech Republic where the proportion is 12 times lower for males than in Turkey in 2014 and about 8 times lower for females. Given that the data covers 25-64 year olds it suggests a relatively high level of general education in the population.

b) In relation to mid-level attainment; the Czech Republic again is distinct in terms of the share of the population for those with ISCED 3-4; a slightly similar picture emerges in Germany although not to the same extreme. While it could be argued that this reflects the strong vocational sector in Germany, in the Czech Republic as we shall see many senior jobs are held by those with only mid-level qualifications representing perhaps the different trajectories of the labour market in the two countries.

c) There has been an increase in all economies presented in the rate of people with high education attainment and the most advanced economy (as measured by the proportion with high level qualifications) would appear to be Finland. It could also be argued that it represents rather the 'public good' nature of free higher education. This is particularly noticeable in relation to the proportion of females with high level qualifications in the Finnish population.

d) Finally, only Spain could be said to exhibit an 'hour glass' economy in terms of the relative share of qualifications in the employed population with a large proportion at either end and a relatively small number with intermediate qualifications.

From a labour market perspective, and related to the policy prescriptions outlined above, the crucial question is, if an increasing number of people with high levels of education can be absorbed into the labour market at an adequate level (Bartlett, 2013 and Flisi et al., 2014). One way to examine this is to look at the level of educational attainment at different levels of the labour market using the International Standard Classification of Occupation (ISCO). ${ }^{19}$ While it might be expected for some people with low levels of education to obtain high level jobs, through performance, progression or innate talent; it is suggested that it is more problematic if large numbers of those with high level qualifications are employed in low level occupations resulting in underemployment, over qualification, or; what is termed a 'mismatch' between qualifications and employment.

An analysis by was undertaken on ISCED (ISCED 2011) occupational classification levels mapped onto ISCO (ISCO-08) labour market categories for adults employed in ISCO 1-9 for males and females aged 25-64 in the partner countries and the EU28 averages for 2007 and $2014 .{ }^{20}$ For the purpose of this analysis we equate ISCED levels 5-8 with ISCO categories 1-3 as matched employment; and ISCED 0-2 with ISCO 8-9. Vocational qualifications are more

$19 \quad$ ISCO is a classification system developed by the International Labour Office (ILO). The latest version is ISCO-08 (ILO, 2105), although EUROSTAT still uses ISCO-88 and it is this version that is applied in this analysis.

20 Tables available on request - of reasons of space only ISCO 1-3 (Managers, professionals, technicians and associate professionals) and ISCO 8-9 (Plant and machine operators and assemblers and elementary occupations) are reported 
difficult to map but while it is imperfect we equate ISCED levels 4-5 with ISCO 4-5 and ISCO 6-7.

In relation to positive mismatch, males in Turkey with low levels of education (14.5\%) are around twice as likely as the EU28 (6.1\%) to have achieved high level occupations (ISCO Levels 1-3); with the Czech Republic having considerably higher proportions of those with ISCED Levels 3-4 having high level jobs in 2007. By 2014 however, this mismatch had been reduced and there had been a rise for all partner countries for those with high educational attainment (ISCED 5-8). One possible interpretation is that in tightening labour markets educational qualification becomes a more important sorting device; while, conversely the reduction in those with low attainment reaching higher level jobs may be a sign of reduced social mobility.

In relation to negative mismatch: for males in 2007, the UK exhibited levels of apparent underutilisation (8.5\%) far higher than other LETAE partners and also the EU28 average (4.5) for those with high-level qualifications in ISCO level 8-9 and while that reduced by 2014, the UK still had more than twice the proportion of those with high levels of attainment (ISCED5-8) in lower level occupations than the Eu28. Interestingly, Spain, specifically in Clerical and Sales occupations (ISCO 4-5) for both males and females, levels of education appear to make little difference to labour market position with relatively large proportions of both high and low qualified in intermediate jobs.

If we look at matching between education and occupation for females a similar picture emerges although the scale of underutilisation is more diverse and this may be related to gender inequality in access to the labour market, structural differences and cultural gender roles. It is suggested that Spain, Turkey and Finland provide the best opportunity for them to realise their potential in terms of achieving employment at a level for which they are educated with 89\%, 84\% and $87 \%$ respectively with higher levels of attainment (ISCED 5-8) in higher level occupations (ISCO 1-3); as with males in higher level occupations, matching at the top end increased by 2014. Finally, when we examine employment at the lower end of the occupational scale (ISCO8-9) we can see what might be considerable underutilisation of females with mid-level qualifications in the Czech Republic and Finland while between 1 in 8 and 1 in 10 in Finland, Spain and the UK with high levels of attainment were in elementary occupations which is around twice the EU28 average (5.8\%) in 2014.

In general, it would appear that since the crisis of 2008 there is increased matching of education to employment levels at the top end of the labour market; although it would also appear that the proportion of those who could be identified as underutilised increased as a result of the recession. The analysis, although open to charges of over simplification does suggests that education is not a guarantee of high-level employment and that in the current labour market there appears to be considerable underutilisation of educational attainment across the partner countries although there is considerable variation both within and across countries and by gender. Correspondingly it also suggests that low qualifications are not an insurmountable barrier to gaining employment in high level occupations as measured by ISCO although this appears to be reducing. In general, it would also appear that the proportion of those who could be identified as underutilised increased as a result of the recession caused by the financial crisis of 2008. In addition, it seems that increasing the rate of people with higher 
education, which is an expressed objective of Europe 2020, may be accompanied by an increasing difficulty for these people to find a job, which is adequate to their education level. ${ }^{21}$

\section{UNIVERSITY - STAKEHOLDER COOPERATION IN ADULT EDUCATION}

\section{THE EUROPEAN LANDSCAPE OF UNIVERSITY LIFELONG LEARNING AND WORK BASED LEARNING}

Lifelong learning at higher education institutions is not the main subject of educational research, but there have been several European projects working on this and related fields. In addition to the THEMP and LETAE projects, there have been a number of projects, which have provided insights on national landscapes. In a number of works derived from these projects, the diversity and complexity of the European landscapes of lifelong learning at universities can be observed (see for instance, Davies (2007a; 2009), de Viron and Davies (2015), and EUA reports: Sursock \& Smidt, (2010) and Smidt \& Sursock, (2011)). Based on survey data de Viron and Davies (2015, p. 55) conclude that LLL is not a high priority for European universities and that: "LLL activities have tended to be introduced in a responsive, but rather ad hoc way, with strategy coming only later (if at all) when further development necessitates a more coherent, institution-wide approach."

University lifelong learning is, however a very broad concept. "What counts as ULLL varies between universities in the same country, between countries and sometimes between faculties in the same institution. The management and organisation similarly varies with different structures and arrangements. The provision of services to support learners following different and flexible paths into and through the institution is extremely patchy and variously organised" (Davies, 2007b, p. 1).

Smidt and Sursock (2011, p. 66) concluded that in the EU, lifelong learning at universities is mainly interpreted in two ways: 1 . Provision of education within a lifelong perspectives including all types of learning: formal, informal and nonformal learning; and. 2. Provision of discrete activities: e.g., professional upgrading, continuing education, distance education, university courses for junior, mature and senior learners, preparatory courses, and part-time education to a greater variety of learners.

In their Trend report; Sursock \& Smidt (2011, p. 68) suggested that professional development courses, continuing education for adults and distance learning are the main lifelong learning activities at higher education institutions.

More directly relevant to the focus of LETAE, the recent Eurydice report Adult Education and Training in Europe: Widening Access to Learning Opportunities (EC 2015a) identified a range of barriers common to those raised in debates on Work-based or - related Learning. The main constraints identified were the difficulties in combining education and training with family life and

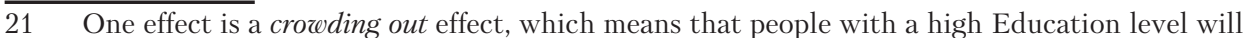
work in an occupation, which in principle is for people with a medium Education level, so that those with a medium level will have problems (crowded out) finding an job commensurate with their level of education. Another effect could be a re-definition of the educational requirements (credentialisation) for jobs classified in occupational groups 4 to 8; and a redefinition of these jobs in the sense of up-skilling. 
responsibilities; time issues in terms of conflicts with work schedules; a lack of prerequisite qualifications and difficulties associated with recognition of prior learning; and a range of financial issues. The report also stressed the need for outreach and guidance activities to raise awareness and provide robust information in the area of WBL; itself the focus of an ELGPN (European Lifelong Guidance Policy Network) Report: Work-based Learning and Lifelong Guidance Policies (Borbély-Pecze \& Hutchinson, 2014)

Another relevant piece of research is provided by the Work Based Learning as Integrated Curriculum (WBLIC) project (2013) funded by the Lifelong Learning Programme aimed at identifying best practice in WBL (see http://www.wblic. org.uk/). They note that the dominant approach to WBL in Europe appears to be through work placements and reflection and that it tends to be concentrated in newer rather than traditional universities (Devins, 2013, p. 28). They also note that alternative routes or permeability into higher education are rare and the UK has a significantly higher proportion (28\% compared to around 5\% in other European countries, Ibid. 5) entering through non-traditional entry routes. In terms of employer engagement they report that the evidence is limited and note that WBL is seldom identified or reported as a distinct entity in strategic policy documents and when it is, the data does not allow a full understanding of its scope and the scale of future potential (Ibid.)

Many of the issues identified above reflect concrete conditions in a number of the LETAE case studies. So too are many of the challenges in relation to: employer engagement, assessment, funding, and costs and benefits to learners, academic institutions and external stakeholders who work in collaboration and/ or partnership to deliver opportunities of work oriented adult education and universities.

\section{PROGRAMMES OF UNIVERSITY ADULT EDUCATION - CASES STUDIES OF SIX EUROPEAN COUNTRIES}

Having provided a range of comparative data on the national landscape in relation to educational attainment and outcomes we return to our case studies. While there is no space here to provide in depth details of the 18 case studies selected for the project; we do provide details of all cases on a number of criteria. However a number of points about the cases should be noted.

While the project laid down a number of selection criteria for case selection, in a number of contexts it was not possible to select programmes that satisfied all criteria for all partners. This is partly explained by the different landscapes and context in operation in the selected countries, and the historical development of the vocational and academic sectors with reference to labour market structures and stratification.

Table 3 attempts to provide some salient information on each of the case studies in the LETAE project. Summary details are provided on a number of indicators including: area of study or industry; duration and cost to the student; the target group and required qualification or employment level for access; how and by whom it is delivered and outcome in terms of certification and credit. 


\section{Table 3}

Selected characteristics of the LETAE case study programmes

\begin{tabular}{|c|c|c|c|c|c|c|c|}
\hline Case & Area of study & $\begin{array}{l}\text { Duration } \\
+ \text { Cost* }\end{array}$ & $\begin{array}{l}\text { Target } \\
\text { Group }\end{array}$ & $\begin{array}{l}\text { Level of } \\
\text { entry - } \\
\text { Access } \\
\end{array}$ & $\begin{array}{l}\text { Delivery } \\
\text { mode }\end{array}$ & Delivery & Credit/award \\
\hline 1 & 2 & 3 & 4 & 5 & 6 & 7 & 8 \\
\hline FI-1 & Bus. Admin & $\begin{array}{l}1-2 \text { years } \\
€ 500 / 4000 \\
\end{array}$ & $\begin{array}{l}\text { HE Admin } \\
\text { staff }\end{array}$ & Masters & $\begin{array}{l}\text { P-t } 2 \text { days/ } \\
\text { week; F2F }\end{array}$ & $\begin{array}{l}\text { Academic + } \\
\text { Experts }\end{array}$ & $\begin{array}{l}40-50 \text { ECTS } \\
+ \text { Certificate } \\
\end{array}$ \\
\hline FI-2 & $\begin{array}{l}\text { Global Health } \\
\text { (Medical/ } \\
\text { Health Aid) }\end{array}$ & $\begin{array}{l}\text { 4-5 weeks } \\
€ 350\end{array}$ & $\begin{array}{l}\text { Health } \\
\text { professionals }\end{array}$ & $\begin{array}{l}\text { At least } \\
\text { Bachelor }\end{array}$ & $\begin{array}{l}\text { F-t } 50 / 50 \\
\text { academic/ } \\
\text { practice; } \\
\text { F2F }\end{array}$ & $\begin{array}{l}\text { Academic + } \\
\text { Experts }\end{array}$ & $\begin{array}{l}8 \text { ECTS + } \\
\text { Diploma/ } \\
\text { certificate }\end{array}$ \\
\hline FI-3 & $\begin{array}{l}\text { Finnish } \\
\text { Language/ } \\
\text { ICT }\end{array}$ & $\begin{array}{l}8 \text { months } \\
\text { Free }\end{array}$ & $\begin{array}{l}\text { External ICT } \\
\text { professionals }\end{array}$ & $\begin{array}{l}\text { Generally } \\
\text { Masters }\end{array}$ & F-t; F2F & $\begin{array}{l}\text { Academic + } \\
\text { Experts }\end{array}$ & $\begin{array}{l}30 \text { ECTS + } \\
\text { Certificate; } \\
\text { National } \\
\text { Language } \\
\text { Certificate }\end{array}$ \\
\hline UK-1 & $\begin{array}{l}\text { Community } \\
\text { development } \\
\text { (Public } \\
\text { Sector) }\end{array}$ & \begin{tabular}{|l|}
3 years \\
Free
\end{tabular} & $\begin{array}{l}\text { Community } \\
\text { workers }\end{array}$ & $\begin{array}{l}\text { Open } \\
\text { restricted }\end{array}$ & $\begin{array}{l}\text { F-t } 60 / 40 \\
\text { academic/ } \\
\text { practice; } \\
\text { F2F }\end{array}$ & $\begin{array}{l}\text { Academic }+ \\
\text { practitioners }\end{array}$ & $\begin{array}{l}\text { Bachelor } \\
\text { degree }+ \\
\text { Professional } \\
\text { Accreditation }\end{array}$ \\
\hline UK-2 & \begin{tabular}{|l|} 
Electrical \\
Power \\
Engineering \\
(Electricity \\
Generators)
\end{tabular} & \begin{tabular}{|l|}
3 years \\
Employer
\end{tabular} & $\begin{array}{l}\text { Existing } \\
\text { workers; new } \\
\text { entrants }\end{array}$ & $\begin{array}{l}\text { University } \\
\text { entry } \\
\text { requirement } \\
\text { employer } \\
\text { selected }\end{array}$ & $\begin{array}{l}\text { Sandwich } 2 \\
\text { week block } \\
\text { release; } \\
\text { final year } \\
\text { in industry; } \\
\text { F2F }\end{array}$ & $\begin{array}{l}\text { Academic + } \\
\text { Enterprise } \\
\text { Specialist } \\
\text { Trainers }\end{array}$ & $\begin{array}{l}\text { Foundation } \\
\text { Degree } \\
\text { (ISCED 5) }\end{array}$ \\
\hline UK & $\begin{array}{l}\text { Production } \\
\text { Engineering } \\
\text { (Jet Engines) }\end{array}$ & $\begin{array}{l}4-6 \text { years } \\
€ 160 \text { per } \\
60 \text { Credits }\end{array}$ & $\begin{array}{l}\text { Shop-floor } \\
\text { workers }\end{array}$ & $\begin{array}{l}\text { Open + } \\
\text { ARPL } \\
\text { restricted to } \\
\text { employees } \\
\end{array}$ & $\begin{array}{l}\text { P-t; } \\
\text { Distance }\end{array}$ & Academic & $\begin{array}{l}\text { Bachelor } \\
\text { degree }\end{array}$ \\
\hline DE-1 & $\begin{array}{l}\text { VET Training } \\
\text { (Engineering) }\end{array}$ & $\begin{array}{l}3 \text { years } \\
\text { Free } \\
€ \underline{18000} \\
\end{array}$ & \begin{tabular}{|l} 
SME \\
employees
\end{tabular} & $\begin{array}{l}\text { Meister, } \\
\text { Technician } \\
\text { (CVET); } \\
\text { (ARPL) }\end{array}$ & $\begin{array}{l}\text { P-t } \\
\text { weekends; } \\
\text { F2F }\end{array}$ & $\begin{array}{l}\text { Academic }+ \\
\text { CVET }\end{array}$ & $\begin{array}{l}\text { CVET } \\
\text { Degree + } \\
\text { Bachelor } \\
\text { degree }\end{array}$ \\
\hline DE-2 & $\begin{array}{l}\text { Industrial } \\
\text { Engineering }\end{array}$ & 3 years & $\begin{array}{l}\text { Graduate } \\
\text { employees }\end{array}$ & Graduate & $\begin{array}{l}\text { P-t } \\
\text { evenings, } \\
\text { work based } \\
\text { projects; } \\
\text { Blended } \\
\end{array}$ & Academic & $\begin{array}{l}\text { Master's } \\
\text { degree }\end{array}$ \\
\hline DE-3 & Aeronautics & 6 months? & \begin{tabular}{|l} 
Top rated \\
apprentices
\end{tabular} & $\begin{array}{l}\text { University } \\
\text { level }\end{array}$ & $\begin{array}{l}\text { P-t; during } \\
\text { work }\end{array}$ & $\begin{array}{l}\text { Academic + } \\
\text { VET }\end{array}$ & Certificate \\
\hline ES-1 & Management & $\begin{array}{l}14 \text { months } \\
\text { Enterprise }\end{array}$ & \begin{tabular}{|l} 
Enterprise \\
middle \\
management
\end{tabular} & $\begin{array}{l}\text { Post } \\
\text { Graduate }\end{array}$ & $\begin{array}{l}\text { P-t, project } \\
\text { based, } \\
\text { Blended }\end{array}$ & $\begin{array}{l}\text { Academic + } \\
\text { Enterprise }\end{array}$ & $\begin{array}{l}\text { University } \\
\text { Certificate }\end{array}$ \\
\hline ES-2 & $\begin{array}{l}\text { Water } \\
\text { Management }\end{array}$ & $\begin{array}{l}700 \text { hours } \\
\text { Enterprise }\end{array}$ & $\begin{array}{l}\text { Enterprise } \\
\text { middle } \\
\text { management }\end{array}$ & $\begin{array}{l}\text { Middle } \\
\text { management }\end{array}$ & $\begin{array}{l}\text { P-t, modular } \\
\text { project } \\
\text { based, } \\
\text { Blended }\end{array}$ & $\begin{array}{l}\text { Academic + } \\
\text { Enterprise + } \\
\text { Specialist }\end{array}$ & $\begin{array}{l}\text { University } \\
\text { Certificate }\end{array}$ \\
\hline ES-3 & $\begin{array}{l}\text { International } \\
\text { Law }\end{array}$ & $\begin{array}{l}88 \text { hours } \\
\text { Enterprise }\end{array}$ & $\begin{array}{l}\text { Enterprise } \\
\text { recruits }\end{array}$ & Graduate & $\begin{array}{l}\text { P-t, } \\
\text { modular, } \\
\text { F2F }\end{array}$ & $\begin{array}{l}\text { Selected } \\
\text { Academics }\end{array}$ & $\begin{array}{l}\text { University } \\
\text { Certificate }\end{array}$ \\
\hline $\mathrm{CZ}-1$ & $\begin{array}{l}\text { Internship } \\
\text { - various } \\
\text { sectors }\end{array}$ & $\begin{array}{l}4 \text { weeks } \\
\text { Free }\end{array}$ & $\begin{array}{l}\text { University } \\
\text { students }\end{array}$ & $\begin{array}{l}\text { University } \\
\text { level }\end{array}$ & $\mathrm{P}-\mathrm{t}, \mathrm{F} 2 \mathrm{~F}$ & Enterprise & $\begin{array}{l}\text { Academic } \\
\text { credit }\end{array}$ \\
\hline $\mathrm{CZ}-2$ & \begin{tabular}{|l|} 
Technology \\
Transfer + IP
\end{tabular} & $\begin{array}{l}3 \text { year } \\
\text { Free }\end{array}$ & $\begin{array}{l}\text { Post-docs, } \\
\text { Lecturers }\end{array}$ & Post-doc & $\begin{array}{l}\text { F-t }+ \\
\text { workshop, } \\
\text { F2F } \\
\end{array}$ & $\begin{array}{l}\text { University } \\
\text { selected } \\
\text { Enterprise } \\
\end{array}$ & No Certificate \\
\hline $\mathrm{CZ}-3$ & IT Internship & \begin{tabular}{|l|}
3 months \\
Enterprise \\
\end{tabular} & \begin{tabular}{|l|} 
University \\
students
\end{tabular} & $\begin{array}{l}\text { University } \\
\text { level }\end{array}$ & $\begin{array}{l}\text { F-t, project } \\
\text { based, F2F }\end{array}$ & Enterprise & $\begin{array}{l}\text { Certificate - } \\
\text { Student fee }\end{array}$ \\
\hline TK-1 & $\begin{array}{l}\text { Airport } \\
\text { Management } \\
\text { and } \\
\text { Aeronautics }\end{array}$ & $\begin{array}{l}30 \text { hours } \\
\text { Enterprise }\end{array}$ & $\begin{array}{l}\text { Selected } \\
\text { managerial } \\
\text { employees }\end{array}$ & $\begin{array}{l}\text { Middle } \\
\text { management }\end{array}$ & P-t F2F & $\begin{array}{l}\text { Selected } \\
\text { Academics }\end{array}$ & $\begin{array}{l}\text { University } \\
\text { Certificate }\end{array}$ \\
\hline
\end{tabular}




\begin{tabular}{|c|l|l|l|l|l|l|l|}
\hline \multicolumn{1}{|c|}{\begin{tabular}{c} 
Continuation of Table 3 \\
\hline 1
\end{tabular}} & \multicolumn{1}{|c|}{2} & \multicolumn{1}{c|}{3} & \multicolumn{1}{c|}{4} & \multicolumn{1}{c|}{5} & \multicolumn{1}{c|}{6} & \multicolumn{1}{c|}{7} & \multicolumn{1}{c|}{8} \\
\hline TK-2 & $\begin{array}{l}\text { Aviation } \\
\text { maintenance }\end{array}$ & $\begin{array}{l}180 \text { hours } \\
\text { Enterprise }\end{array}$ & $\begin{array}{l}\text { Academic } \\
\text { staff }\end{array}$ & $\begin{array}{l}\text { High School } \\
\text { Teachers }\end{array}$ & $\begin{array}{l}\text { P-t, work } \\
\text { based } \\
\text { elements } \\
\text { F2F }\end{array}$ & $\begin{array}{l}\text { Selected } \\
\text { Academics }\end{array}$ & $\begin{array}{l}\text { University } \\
\text { Certificate }\end{array}$ \\
\hline TK-3 & Logistics & $\begin{array}{l}120 \text { hours } \\
\text { ??? }\end{array}$ & $\begin{array}{l}\text { Mid } \\
\text { management } \\
\text { employees }\end{array}$ & Open & P-t, F2F & $\begin{array}{l}\text { Selected } \\
\text { Academics }\end{array}$ & $\begin{array}{l}\text { University } \\
\text { Certificate }\end{array}$ \\
\hline
\end{tabular}

Of the 18 cases, seven were focused on managerial or professional level staff, while another six were in engineering related fields with the remainder more diverse. In terms of duration seven of the cases were six months or less and often part-time; while six were long-term and involved at least three years commitment by the learner. Eleven of the cases were focused on post-graduate learners with an existing degree with only four cases focusing on upskilling existing workers in a specific field and this is reflected in the entry requirements required. Six of the cases were based on full-time attendance and while three of the part-time cases included blended learning, only UK-3 operated on a distance model. In relation to the delivery of the programmes nine of the cases were delivered by solely by academic staff or in conjunction with practitioners and specialists in the relevant field; while in the Spanish and Turkish cases academics were selected and then retained (or not) based on programme evaluation. Finally, in terms of outcomes, the Spanish and Turkish cases offered University Certificates outside of formal recognition (Bologna) structures. The Turkish cases were short duration vocational further training provided by universities; while the Spanish cases were postgraduate programme certified by individual universities outside of the Bologna scheme. The Finish cases all offered transferable ECTS points and a Certificate. The three UK cases all led to the award of a recognised qualification at ISCED 5 or 6. Two of the German programmes led to certificates within the Bologna Scheme (Bachelors) and the third was a programme preparing for participation in Bachelor programmes. In contrast the Czech cases, perhaps representing the lower level of adult work related learning, offered certificates of completion or institutional credits.

While there is no room here to give a detailed exposition of the differences in the partner countries it is suggested that it is possible to infer some general characteristics in relation to the general orientation of university adult education in the six partner states (see Eurydice https://webgate.ec.europa.eu/fpfis/ mwikis/eurydice/index.php/Countries). It is suggested that Finnish, Spanish and Turkish universities tend to focus on continuous training programmes. While Turkish universities include VET centres, their programmes address a broad range of learners but tend to be very short in duration and might be considered as CPD. In comparison, the Finnish and Spanish universities have a specific focus on postgraduate continuous training. In the Finnish case, as noted, this is within existing and national award structures and ECTS points should be recognised across EU member states; in the Spanish cases, while two award University Masters these are not recognised at a national or international level which is linked to the specific structure of its education system, outlined in more detail below.

In Germany and the UK/(Scotland), the focus lies more on the issue of permeability and transferability, that facilitates in theory at least the access of people with non-academic entry qualifications to degree level. This does not 
mean that universities in both countries do not offer postgraduate adult learning programmes, but the main focus of the policies lies on the integration of nontraditional learners through officially certified programmes. The cases selected in Germany are two bachelor programmes specifically designed for adult learners and one programme, which prepares adults for their participation in bachelor programmes. The three UK cases each target a specific group but all are closely linked to the learner's current employment and two of the programmes also allow professional accreditation in addition to the formal degree award.

Finally, as suggested above the Czech Republic is a specific case, as the development of adult education at universities seems to be in its initial phase and has not yet acquired a specific profile and this is perhaps a result of it specific context given the relatively high historical levels of educational attainment noted earlier.

\section{SOME CONCLUDING REMARKS}

We have set out above an overview of various aspects of work-based and related learning in higher education involving partnerships and collaboration with external stakeholders. We have positioned this study within the context of various EU and national policy documents which call for the creation of a highskilled workforce to effectively harness the high value and high skill employment opportunities said to be required in the knowledge economy. We have noted that despite some limited successes, the scale and scope of cooperation in work based and related learning has not developed to the extent that was envisaged. Bottlenecks still exist in relation to the recognition and accreditation of prior learning and experience; and despite some success genuine partnerships between enterprises and or sectoral organisations appear to be thin on the ground.

We also noted some differences within and across the partner countries and how this and national policy and educational structures can hinder or enhance greater collaboration between both academic and vocational sectors but also in promoting collaborations partnerships with industry and trade unions.

Finally we want to call the attention, that all 6 programmes analysed in the LETAE project were focused on employed people or in the case of the first UK programme, that they are working at least as volunteers in the field. It can be suggested that in the case of participation of unemployed people in university adult education programmes, the linkage to work processes will be more difficult.

Returning to the distinction between public interest, capital or work as driving forces behind the programmes, we observe that in four of the programmes capital is the driver, in one the trade union as organised representative of work, and in one case the public interest. Extending this perspective to the Spanish open programmes, we observe a diffuse interest of capital and unorganised work behind the programmes detected by the academics. The public interest has only a subsidiary role in partially funding the participation. That means, it is still an open question if the university will offer adult education programmes in public interest beyond the interest of the state to obtain a high-qualified work forces for their public services. In other words, it is an open question if the universities are able and willing to provide programmes of public interest for people, who are in critical labour positions, for instance highly-educated unemployed persons looking for new opportunities. 
This seems a more relevant question for the future, in which the rate of highlyeducated people will expand. In spite of us having injected some caution to our analysis, we have observed that the sub-utilization of highly-educated work forces has been recurrent in the last decade in spite of its variation from country to country. And recent analysis of the labour market has suggested that since the crisis many of the new jobs which have been created have been in the low-skill and low paid sector. According to the European Commission (EC 2012, p. 31): "Fluctuations in EU job numbers since the crisis began have been driven mainly by part-time work and temporary contracts."

This is given some credence by the findings of European Jobs Monitor 2015 (Eurofound, 2015, p. 1) which notes that recent trends indicate a downward skew in employment distribution with more growth in lower-paid employment and comment that this "raises the spectre of growing low-productivity employment, where output and, ultimately, living standards fail to rise despite an increase in job opportunities."

This indicates that equating higher education as access to good jobs - also considering the trend towards generalisation of higher education promoted by the actual EU strategy Europe 2020 - is not valid any more in many EU-countries. This suggests that, in the future major social investments in continuous training and governments must provide an adequate offer of tertiary adult education oriented to the labour market to support people in critical periods of labour market transitions. And that this requires a greater degree of cooperation between higher education institutions including universities; and stakeholders to provide adequate training and education provisions.

\section{REFERENCES}

Allen, M. (2015). 'Hard Labour': Young people moving into work in difficult times. Radicaled Books. Retrieved from https://radicaledbks.files.wordpress. com/2013/09/hard-labour-oct-151.pdf

Bartlett, W. (2013). Skill Mismatch, Education Systems, and Labour Markets in EU Neighbourhood Policy countries. Sharing KnowledgE Assets: InteRregionally Cohesive NeigHborhoods (SEARCH) WP5.20. Consulted 19/09/2016. Retrieved from http://www.ub.edu/searchproject/wp-content/ uploads/2013/09/WP05.20.pdf

Bell, D. N. F., \& Blanchflower, D. G. (2013). Under-employment in the UK revisited. National Institute Economic Review 224(1): F8-F21.

Borbély-Pecze, T. B., \& Hutchinson, J. (2014). Work-based Learning and Lifelong Guidance Policies. ELGPN Concept Note No. 5. Consulted 19/09/2016. Retrieved from http://www.elgpn.eu/publications/ elgpn-concept-note-no--5-work-based-learning-and-lifelong-guidance-policies

Buhr, R., Freitag, W., Hartmann, E. A., Loroff, C., Minks, K.-H., \& Stamm-Riemer, I. (Eds.). (2008). Durchlässigkeit gestalten! Wege zwischen beruflicher und hochschulischer Bildung, Münster, Waxmann.

CEDEFOP (2011). Vocational education and training at higher qualification levels. Research Paper No 15. Consulted 19/09/2016. Retrieved from http://www. cedefop.europa.eu/files/5515_en.pdf

CEDEFOP (2012). The development of ECVET in Europe. Luxembourg. Consulted 19/09/2016. Retrieved from http://www.cedefop.europa.eu/ files/6114_en.pdf 
Council of the European Union (2011). Council conclusions on the role of education and training in the implementation of the 'Europe 2020' strategy. (2011/C 70/01). In Official Journal of the European Union 4.3.2011 C 70/1 - 3. Consulted 19/09/2016. Retrieved from http://eur-lex.europa.eu/legal-content/ EN/TXT/?uri=OJ:C:2011:070:TOC

Davies, P. (2007a). The Bologna Process and University Lifelong Learning: The State of Play and future Directions. Barcelona, Spain. Consulted 19/09/2016. Retrieved from http://www.eucen.eu/BeFlex/FinalReports/ BeFlexFullReportPD.pdf

Davies, P. (2007b). The Bologna Process and University Lifelong Learning: The State of Play and future Directions. Executive Summary. Barcelona, Spain. Consulted 19/09/2016. Retrieved from http://www.eucen.eu/BeFlex/FinalReports/ ExecutiveSummaryWEBversion.pdf

Davies, P. (2009). From University Lifelong Learning (ULLL) to Lifelong Learning Universities (LLLU). BeFlex Plus - Progress on flexibility in the Bologna Reform. Executive Summary. Barcelona, Spain: EUCEN.

Devins, D. (2013a). A REVIEW OF CASE STUDY FINDINGS: Deliverable 4: Work Based Learning as an Integrated Curriculum (WBLIC). Consulted 19/09/2016. Retrieved from http://www.wblic.org.uk/wblhe/files/WBLIC_Case_Study_ Findings.pdf

Devins, D. (2013b). Overview of Work Based Learning in Europe. Deliverable 6: Work based learning as an Integrated Curriculum. Consulted 19/09/2016. Retrieved from http://www.wblic.org.uk/wblhe/files/WBLIC_Overview_of_ WBL_in_Europe.pdf

De Viron, F., \& Davies, P. (2014). From University Lifelong Learning to Lifelong Learning Universities - developing and implementing effective strategy. In Yang, J. \& Schneller, C. \& Roche, S. (Eds.). The Role of Higher Education in Promoting Lifelong Learning. UNESCO Institute for Lifelong Learning. Hamburg, Germany, 40-59.

EGEA Ministerial Conference (2015). The Bologna Process Revisited: the Future of the European Higher Education Area; Yerevan, Armenia.

EUNEC (2011). Participation and Stakeholder Involvement in Education Policy Making. Retrieved from http://www.eunec.eu/sites/www.eunec.eu/files/ event/attachments/report_brussels.pdf

Eurofound (2015). Upgrading or polarisation? Long-term and global shifts in the employment structure: European Jobs Monitor 2015. Publications Office of the European Union, Luxembourg. Consulted 19/09/2016. Retrieved from http://www.eurofound. europa.eu/sites/default/files/ef_publication/field_ef_ document/ef1516en_0.pdf

(EC) European Commission (2006). Delivering on the Modernisation Agend for Universities: Education, Research and Innovation. Brussels, 10.5.2006. COM(2006) 208 final. Consulted 19/09/2016. Retrieved from http:// ec.europa.eu/invest-in-research/pdf/comuniv2006_en.pdf

(EC) European Commission, European Ministers for Vocational Education and Training; and European Social Partners (2010). The Bruges Communiqué on enhanced European Cooperation in Vocational Education and Training for the period 2011-2020. Bruges. Consulted 19/09/2016. Retrieved from http://ec.europa.eu/education/lifelong-learning-policy/doc/vocational/ bruges_en.pdf 
(EC) European Commission (2011). Supporting growth and jobs - An agenda for the modernisation of Europe's higher education systems. Brussels. COM (2011) 567 final. Consulted 19/09/2016. Retrieved from http://eur-lex.europa.eu/ legal-content/EN/TXT/PDF/?uri=CELEX:52011DC0567\&from=EN

EC (2012). Rethinking Education: Investing in skills for better socio-economic outcomes, COM (2012) 669 final. Retrieved from http://eur-lex.europa.eu/ legal-content/EN/TXT/PDF/?uri=CELEX:52012DC0669\&from=EN

EC (2012b). Employment and Social Developments in Europe 2012, Publications Office of the European Union, Luxembourg, 2012 (p.31). Retrieved from http://ec.europa.eu/ social/BlobServlet?docId=9604\&langId=en

(EC) European Commission (2013). Work-Based Learning In Europe: practice and policy pointers. Retrieved from http://ec.europa.eu/education/opportunities/ vocational/documents/work-based-learning-in-europe_en.pdf

(EC) European Commission/EACEA/Eurydice (2015a). Adult Education and Training in Europe: Widening Access to Learning Opportunities. Eurydice Report. Luxembourg. Consulted 19/09/2016. Retrieved from http://eacea. ec.europa.eu/education/eurydice/documents/thematic_reports/179EN.pdf

(EC) European Commission (2015b). ECTS Users' Guide. Luxembourg. Consulted 19/09/2016. Retrieved from http://ec.europa.eu/education/ects/users-guide/ docs/ects-users-guide_en.pdf

European Ministers of Education (1999). Bologna Declaration. Consulted 19/09/2016. Retrieved from www.magna-charta.org/resources/files/ BOLOGNA_DECLARATION.pdf

European Union (2011). Supporting growth and jobs - An agenda for the modernisation of Europe's higher education systems. Brussels. COM (2011) 567 final.

Eurydice - European Commission (2014). National student fee and support systems in European higher education. 2014/15. Consulted 19/09/2016. Retrieved from http://bookshop.europa.eu/en/national-student-fee-and-supportsystems-in-european-higher-education-pbECAE15001/downloads/EC-AE15-001-EN-N/ECAE15001ENN_002.pdf?FileName=ECAE15001ENN_002. pdf \&SKU=ECAE15001ENN_PDF\&CatalogueNumber=EC-AE-15-001-EN-N

Eurydice (2015). United Kingdom - Organisation of Private Education. Posted 07/01/105. Consulted 19/09/2016. Retrieved from https://webgate.ec.europa.eu/fpfis/mwikis/eurydice/ index.php/ United-Kingdom-England:Organisation_of_Private_Education

Field, J. et al. (2012). Life history approaches to access and retention of nontraditional students in higher education: A cross-European approach, European Journal for Research on the Education and Learning of Adults, 3 (1), 77-89.

Flisi, S. et al. (2014). Occupational mismatch in Europe: Understanding overeducation and overskilling for policy making. European Commission, Joint Research Centre, Institute for the Protection and Security of the Citizen. Retrieved from https://ec.europa.eu/jrc/sites/default/files/occupational_ mismatch_in_europe.pdf

Harwood, J. (2010). Understanding Academic Drift: On the Institutional Dynamics of Higher Technical and Professional Education. In Minerva; December 2010, Volume 48, Issue 4, 413-427.

Hippach-Schneider, U. (2014). Academisation or Vocational Drift? International developments in the tertiary sector of education. Bundesinstitut für 
Berufsbildung (BIBB). Retrieved from https://www.bibb.de/dokumente/pdf/ BWP_4-2014_HS_en.pdf

Hughes, T., Porter, A., Jones, S., \& Sheen, J. (2013). Privately funded providers of higher education in the UK. BIS Research paper No. 111. London, UK. Consulted 19/09/2016. Retrieved from https://www.gov.uk/government/uploads/ system/uploads/attachment_data/file/207128/bis-13-900-privately-fundedproviders-of-higher-education-in-the-UK.pdf

Kuhn, H.-J., Baethge, M., Hinz, P., Löhrmann, S., Poltermann, A., Stern, C., Tenorth, H.-E., \& Volkholz, S. (2009). Bildungsgerechtigkeit im LebenslaufDamit Bildungsarmut nicht weiter vererbt wird. Berlin, Deutschland: Heinrich Böll Stiftung.

Krüger, K., \& Jiménez, J. (2008). The social function of higher education in the social models of the European knowledge society. Final Report of NESOR Project. Barcelona, , Spain.

Kyvik, S. (2007). 'Academic drift - A reinterpretation', in: The Officers and Crew of HMS Network (Ed.), Towards a Cartography of Higher Education Policy Change. A Festschrift in Honour of Guy Neave, CHEPS: Enschede, 333-338.

Lafont, P., \& Pariat, M. (2012). Review of the Recognition of Prior Learning in Member States in Europe. Consulted 19/09/2016. Retrieved from http://www. adam-europe.eu/prj/9626/prd/4/1/ReportReview\%20Of\%20The\%20RPL\%20 In\%20Member\%20States\%20In\%20Europe.pdf

Leroux, J.-Y. (2014). The professionalisation of degree courses in France: New issues in an old debate. Higher Education Management and Policy, Vol. 24/3.

Mayer, K. U., \& Solga, H. (Eds.) (2008). Skill formation: Interdisciplinary and crossnational perspectives. New York, US: Cambridge University Press.

Meyer, J. W., Ramirez, F.O., Rubinson, R., \& John, Boli-Bennett (1977). The World Educational Revolution, 1950-1970. In Sociology of Education 50; October 1077, 242-258.

OECD (2012). Post-Secondary Vocational Education and Training: Pathways and Partnerships. Retrieved from http://www.oecd-ilibrary.org/education/ post-secondary-vocational-education-and-training_9789264097551-en

OECD (2014). Education at a Glance 2014: OECD Indicators. Paris.

Ramage, C. (2014). Learning to learn through university accredited work-based learning: a threshold conception; in Journal of Workplace Learning, Vol. 26 Issue: 8, 488-510.

Reeve, F., Gallacher, J., \& Ingram, R. (2007). A comparative study of work-based learning within Higher Nationals in Scotland and Foundation Degrees in England: contrast, complexity, continuity; in Journal of Education and Work. Vol. 20. Issue 4, 305-318.

Schofer, E., \& Meyer, J. W. (2005). The Worldwide Expansion of Higher Education in the Twentieth Century. In American Sociological Review, 70, 898-920.

Scottish Funding Council (2014). Higher Education Students and Qualifiers at Scottish Institutions, 2012-13. SFC Statistical publication. Posted 27 March 2014, Consulted 19/09/2016. Retrieved from http://www. sfc.ac.uk/web/FILES/Statistical_publications__SFCST042014 HigherEducationStudentsandQualifiersatS/Higher_Education_Students_ and_Qualifiers_at_Scottish_Institutions_2012-13_31_March.pdf

Skorstad, E. J., \& Ramsdal, H. (Eds.) (2009). Flexible Organizations and the New Working Life: A European Perspective. Farnham, UK: Ashgate, 193. 
Smeby, J.-C. (2015). Academic drift in vocational education? In Smeby, J.-C., \& Sutphen, M. (2015). From Vocational to Professional Education. Educating for social welfare. Oxon/New York. For the area of social work in Germany see Kruse, E. (2003). Stufen zur Akademisierung. Dissertation. Siegen.

Smidt, H., \& Sursock, A. (2011). Engaging in Lifelong Learning: Shaping Inclusive and Responsive University Strategies. Brussels: European University Association. Also on line. Retrieved from http://www.eua.be/pubs/Engaging_in_Lifelong_ Learning.pdf

Solga, H. (2009). Der Blick nach vorn: Herausforderungen an das deutsche Ausbildungssystem. WZB Discussion Paper SP I 2009-507. Berlin, Deutschland, Social Science Research Center (WZB).

Standing, G. (2011). The Precariat: The New Dangerous Class. London, UK.

Streeck, W. (2012). Skills and Politics: General and Specific. IN Busemeyer, M. R., \& Trampusch, C. (Eds.). The Political Economy of Collective Skill Formation. Oxford, UK: Oxford University Press, 317-352.

Sursock, A., \& Smidt, H. (2010). Trends 2010: A decade of change in European Higher Education. Brussels. Consulted 19/09/2916. Retrieved from http://eua. be/Libraries/publications-homepage-list/trends_2010049364ca84b96a879ce5ff 00009465c7.pdf?sfvrsn $=0$

Teichler, U. (1999). Higher education policy and the world of work: changing conditions and challenges; in Higher Education Policy, 12, 285-312.

Teichler, U. (2007). Does Higher Education Matter? Lessons from a Comparative Graduate Survey. European Journal of Education, 42, 1.

Trow, M. A. (1974). Problems in the Transition from Elite to Mass Higher Education. Carnegie Commission on Higher Education Berkeley

Trow, M. A. (2005) Reflections on the Transition from Elite to Mass to Universal Access: Forms and Phases of Higher Education in Modern Societies since WWII in ALTBACH, P (ed.) International Handbook of Higher Education. pp 243-280. It is republished as Trow, M. A. (2010) Problems in the transition from Elite to Mass Education. in Burrage, M. (2010) Martin Trow. Twentieth Century higher education. From elite to Mass to Universal.

UNESCO Institute for Statistics (2012). International Standard Classification of Education. ISCED 2011. Montreal, Canada. Retrieved from http://www.uis. unesco.org/ Education/Documents/isced-2011-en.pdf

Windolf (1992). Cycle of expansion in higher education 1870 - 1985: an international comparison; in Higher education 23; pp: 3-19.

Yang, J., Schneller, C., \& Roche, S. (Eds.) (2015). The Role of Higher Education in Promoting Lifelong Learning. UNESCO Institute for Lifelong Learning. Hamburg

Yin, R. K. (1994). Case study research. Design and Methods. London.

Yorke, M., \& Knight, P. T. (2006). Embedding employability into the curriculum. The Higher Education Academy. Learning and Employability Series 1. Consulted 19/09/2016. Retrieved from https://www.heacademy.ac.uk/system/files/ id460_embedding_employability_into_the_curriculum_338.pdf 